ISSN 1979-5572 (print)

ISSN 2541-6480 (online

http://ejurnal.iainpare.ac.id/index.php/kuriositas

\title{
KURIOSITAS
}

Media Komunikasi Sosial dan Keagamaan

\begin{tabular}{lll}
\hline Volume 11 & No. 2, Desember 2018 & Halaman 122-134 \\
\hline
\end{tabular}

\section{MULTIMEDIA INTERAKTIF DALAM MENINGKATKAN MOTIVASI BELAJAR AQIDAH AKHLAK}

\author{
Yuslinda \\ Institut Agama Islam Negeri Parepare \\ yuslinda@stainparepare.ac.id
}

\begin{abstract}
This article was focused on obtaining empirical data about the learning motivation of morality before it being taught by using interactive multimedia and obtain information whether the application of interactive multimedia can increase students 'motivation to learn at the Islamic Boarding Schools Darul' Ulum Ath-Thahiriyah.The research design used was one group pre tes and post tes design experiments, which means that in this experimental study there was only one experimental group. Subjects are subject to two measurements. The first measurement is done to measure the motivation of students to follow the process of learning the akidah akhlak (pre tes). The second measurement is measuring the motivation of students after following the akidah moral learning process (post tes).The results of this study are: (1) Motivation of students to follow the process of learning the akidah akhlak before being given treatment in the form of the application of interactive multimedia belonging to the high category. (2) The motivation of students to follow the moral learning process after being given treatment in the form of increased interactive multimedia application.. It shows that there is a significant relationship between the application of interactive multimedia with the improvement of learning motivation of students, so that the proposed hypothesis is accepted, that the application of interactive multimedia is effective in increasing the learning motivation of students to follow the learning process of morality.
\end{abstract}

Keywords: interactive multimedia, learning motivation, morality

\begin{abstract}
ABSTRAK
Tujuan penelitian ini adalah untuk memperoleh data empiris tentang motivasi belajar aqidah akhlak sebelum diajar menggunakan multimedia interaktif dan
\end{abstract}


untuk memperoleh informasi apakah penerapan multimedia interaktif dapat meningkatkan motivasi belajar peserta didik di MTs Pondok Pesantren Darul 'Ulum Ath-Thahiriyah. Desain penelitian yang digunakan adalah eksperimen one group pre tes and post tes design, yang berarti dalam penelitian ekperimental ini hanya ada 1 kelompok eksperimental. Subjek dikenai dua kali pengukuran. Pengukuran yang pertama dilakukan untuk mengukur motivasi peserta didik mengikuti proses pembelajaran akidah akhlak (pre tes). Pengukuran kedua yaitu mengukur motivasi peserta didik setelah mengikiuti proses pembelajaran akidah akhlak (post tes). Hasil penelitian ini adalah: (1) Motivasi peserta didik mengikuti proses pembelajaran akidah akhlak sebelum diberi perlakuan berupa penerapan multimedia interaktif tergolong dalam kategori tinggi (2) Motivasi peserta didik mengikuti proses pembelajaran akidah akhlak sesudah diberi perlakuan berupa penerapan multimedia interaktif meningkat. Hal itu menunjukkan adanya hubungan yang signifikan antara penerapan multimedia interaktif dengan peningkatan motivasi belajar peserta didik, sehingga hipotesis yang diajukan diterima, yaitu penerapan mulimedia interaktif efektif meningkatkan motivasi belajar peserta didik mengikuti proses pembelajaran akidah akhlak.

Kata kunci: multimedia interaktif, motivasi belajar, akidah akhlak.

\section{PENDAHULUAN}

Mata pelajaran akidah akhlak merupakan salah satu mata pelajaran pendidikan agama Islam di Madrasah Tsanawiyah. Pembelajaran akidah adalah internalisasi Islam atau keyakinan pada Allah swt. yaitu bagaimana cara atau proses interaksi pembelajaran agar mempunyai keyakinan Islam atau keyakinan kepada Allahswt. yang kuat.Sebagaimana firman Allah swt. dalam QS. Fushshilat/41: 22-23;

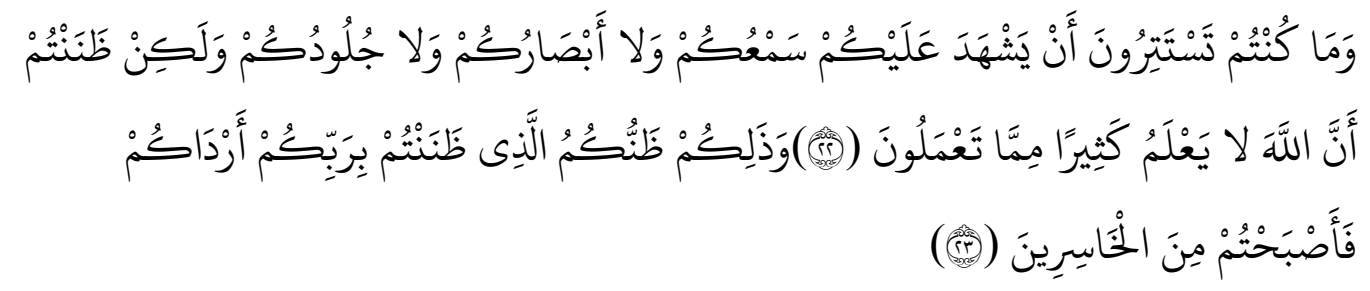

Terjemahnya:

Dan kamu tidak dapat bersembunyi dari kesaksian pendengaran, penglihatan dan kulitmu terhadapmubahkan kamu mengiraAllah tidak mengetahui banyak tentang apa yang kamu lakukan. Dan itulah dugaanmu yang telah kamusangkakan terhadap Tuhanmu, (dugaan itu) telah membinasakan kamu,sehingga jadilah kamu termasuk orang yang rugi.

Pembelajaran akhlak berarti pembelajaran tentang bentuk batin seseorang yang kelihatan pada tindak tanduknya atau tingkah lakunya, didalam pelaksanaan pembelajaran berarti bagaimana proses kegiatan pembelajaran 
dalam mencapai tujuan supaya yang diajar memiliki akhlak yang baik. Untuk mencapai hal tersebut maka cara dan proses pembelajaran akidah akhlak harus dapat mengembangkan seluruh potensi peserta didik. Hal tersebut ditegaskan firman Allah SWT dalam QS.Al-Mu'minun/23: 78;

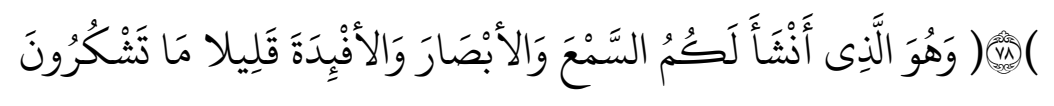

Terjemahnya:

Dan Dia-lah yang telah menciptakan bagimu pendengaran, penglihatan, dan hati nurani, tetapi sedikit sekali kamu bersyukur.

Pengamatan awal yang dilakukan di Madrasah Tsanawiyah (MTs) Pondok Pesantren Darul 'Ulum Ath-Tahiriyah Paladang menunjukkan bahwa guru yang mengajar akidah akhlak hanya menggunakan media buku paket dalam pembelajaran, mengakibatkan peserta didik tidak dapat mengembangkan potensi yang dimiliki, tidak ada semangat, merasa bosan dan tidak bisa bertahan lama di kelas saat proses pembelajaran. Hal ini menyebabkan mata pelajaran akidah akhlak kurang diminati oleh peserta didik, padahal seharusnya mata pelajaran akidah akhlak menjadi pelajaran yang dapat membuat peserta didik memiliki akidah yang kuat kepada Allah swt. dan akhlak yang mulia.

Budaya belajar di MTs Pondok Pesantren Darul 'Ulum Ath-Tahiriyah Paladang hanya ditandai oleh tulisan dan hafalan dibanding budaya belajar menyenangkan. Akibatnya, pelajaran akidah akhlak hanya dipandang sebagai mata pelajaranmenulis dan menghafal. Tidak dipandang sebagai mata pelajaran yang urgen dan menyenangkan. Kondisi ini tidak hanya tampak pada prilaku peserta didik, akan tetapi pada guru dan kebijakan kepala sekolah serta harapan orangtua. Akibatnya proses pembelajaran ditekankan kepada banyaknya catatan materi ajar peserta didik, sehingga pencatatan materi menggunakan buku paket lebih banyak dilakukan dan dipandang lebih efektif dalam mencapai tujuan tersebut dan penggunaan media pembelajaran berbasis multimedia hanya dipandang sebagai suatu hal yang rumit dan dapat memberikan pengaruh negatif terhadap peserta didik.

Proses pembelajaran akidah akhlak dan sarana yang dimiliki oleh sekolah belum dioptimalkan pemanfaatannya untuk menunjang pembelajaran. Keterbatasan-keterbatasan itu antaranya adalah guru masih sering menggunakan media yang telah tersedia yaitu textbook, selain itu metode ceramah dan dikte masih mendominasi dalam proses pembelajaran sehingga model pembelajaran cenderung teacher centered, laboratorium komputer digunakan untuk penggunaan komputer secara umum, peserta didik dilarang membawa handphone, dan laptop ke sekolah, media pembelajaran akidah akhlak berbasis multimedia belum ada di sekolah. 
Rumusan masalah yang akan dijawab pada tulisan ini adalah apakah penerapan multimedia interaktif dapat meningkatkan motivasi belajar akidah akhlak?

\section{METODE}

Jenis penelitian ini adalah penelitian eksperimen. Penelitian eksperimen merupakan metode inti dari model penelitian yang menggunakan pendekatan kuantitatif.

Desain penelitian yang digunakan adalah eksperimen one group pre tes and post tes design, yang berarti dalam penelitian ekperimental ini hanya ada 1 kelompok eksperimental. Subjek dikenai dua kali pengukuran. Pengukuran yang pertama dilakukan untuk mengukur motivasi peserta didik mengikuti proses pembelajaran akidah akhlak (pre tes). Pengukuran kedua yaitu mengukur motivasi peserta didik setelah mengikiuti proses pembelajaran akidah akhlak (post tes). Tahapan penelitian yaitu; rancangan penelitian; Memberikan pre-tes pada sampel; perlakuan/treatment; melakukan post tes pada sampel; bagan rancangan pretes posttes design

$$
\mathrm{O}_{1} \longrightarrow \mathrm{X} \longrightarrow \mathrm{O}_{2}
$$

Keterangan :

$\mathrm{O}_{1} \quad=$ Pre-tes (pengukuransebelum diberi perlakuan)

$\mathrm{O}_{2} \quad=$ Post tes (pengukuran setelah diberi perlakuan)

$X \quad=$ Perlakuan/ treatment

Adapun teknik sampling yang digunakan peneliti dalam menentukan jumlah sampel eksperimen adalah teknik non probability sampling yaitu purposive sampling.

Metode yang digunakan untuk memperoleh data lapangan, yaitu sebagai berikut: a) Observasi adalah mengamati secara langsung proses pembelajaran yang dilakukan guru akidah akhlak di kelas dan menanyai beberapa peserta didik tentang media yang digunakan guru dalam mengajar akidah akhlak di MTs Pondok Pesantren Darul 'Ulum Ath-Thahiriyah Paladang. Selain itu pada proses perlakuan/treatment yang dilakukan selama empat kali kemudian dilakukan observasi terhadap kegiatan dan situasi belajar peserta didik; b) Tes motivasi adalah cara untuk mengumpulkan data mengenai penggunaan media pembelajaran interaktif berbentuk pengajuan pernyataan tertulis tentang motivasi melaui sebuah daftar pernyataan yang sudah disiapkan sebelumnya. Daftar pernyataan tersebut diujikan dua kali pada pre tes dan post tes.

Instrumen yang digunakan yaitu tes motivasi adalah sejumlah peryataan mengenai motivasi (tes motivasi) yang diberikan kepada peserta didik sebelum 
dan setelah diberikan perlakuan. Dalam hal ini sebelum dan setelah diajar menggunakan media pembelajaranakidah akhlak berbasis multimedia interaktif. Pengukuran variable motivasi mengikuti proses pembelajaran akidah akhlak berbasis multimedia interaktif menggunakan skala psikologi yaitu motivasi. Adapun pengembangan alat ukur ini berdasarkan pada indikator dari variabel motivasi.

Adapun tahap-tahap eksperimen diuraikan sebagai berikut:

Pertemuan pertama, sebelum membuka proses pembelajaran maka hal yang pertama dilakukan adalah mempersiapkan alat. Alat yang dipakai untuk multimedia interaktif yaitu laptop, LCD, dan speaker. Setelah menyiapkan alat kemudian membuka proses pembelajaran dengan menyapa peserta didik dan perkenalan. Materi yang pertama ditampilkan pada multimedia interaktif yaitu judul materi "Iman Kepada Rasul Allah swt". Setelah judul ditampilkan maka pada slide kedua ada video yang berisi nyayian tentang 25 nabi dan rasul yang wajib dipercayai, setelah ditampilkan sebanyak dua kali maka peserta didik diminta untuk mengikuti nyanyian tersebut. Setelah bernyanyi dan menghafal nama-nama nabi dan rasul maka dilanjutkan pada materi selanjutnya yaitu pengertian nabi dan rasul, pada materi ini ada dua slide tampilan. Tampillah yang kedua menanyakan tentang "Apakah pelajar tahu pengertian nabi dan rasul?" Sebelum dijelaskan tentang pengertian nabi dan rasul maka pertanyaan yang ada di slide tersebut harus terlebih dahulu dijawab oleh peserta didik. Setelah beberapa jawaban muncul maka dilanjutkan ke slide berikutnya dengan menampilkan pengertian nabi lebih dahulu kemudian pada slide ke dua ditampilkan pengertian rasul. Peserta didik membaca tiap tampilan sambil dijelaskan maksud dari pernyataan yang ada pada slide untuk lebih memperjelas maksud pengertian nabi dan rasul tersebut. Setelah itu dilakukan "uji minda", pada uji minda ini ditampilkan slide yang berisi pertanyaan "Apa pengertian nabi dan rasul?" Pertanyaan ini berupa pertanyaan uraian, maka dari itu diminta kepada peserta didik untuk menjawab pertanyaan yang ada pada slide yang ditampilkan. Setelah beberapa orang menjawab pertanyaan dengan benar maka ditampilkan slide berikutnya yang berisi pertanyaan pilihan ganda tentang "Tahukah Anda berapa orang bilangan rasul yang wajib diketahui?" Kemudian peserta didik disuruh memilih jawaban yang paling benar. Proses pembelajaran pada pertemuan pertama telah selesai dan lanjut pada pertemuan kedua.

Pertemuan kedua, seperti pada pertemuan pertama, sebelum memulai proses pembelajaranmaka hal pertama yang dilakukan adalah menyiapkan alat pembelajaran. Seperti pada pertemuan pertama alat yang disiapkan adalah laptop, LCD dan speaker. Setelah menyiapkan alat pembelajaran maka proses pembelajaran dibuka dengan mengucapkan salam dan berdoa sebelum 
belajar.Sebelum lanjut ke materiselanjutnya maka peserta didik diputarkan video nyayian 25 nabi, dan rasul untuk merefresh ingatan pada pertemuan pertama. Pemutaran video cukup 3kali kemua peserta didik langsung ikut bernyanyi. Setelah itu kemudian ditampilkan slide berikutnya dengan materi "nama-nama rasul yang wajib diketahui" kemudian slide berikutnya berisi pertanyaan tentang “Ingatkah anda nama-nama 25 orang rasul yang wajib diketahui?" kemudian peserta didik menjawag dengan serentak namun masih ada beberapa yang ragu-ragu untuk menjawab. Setelah peserta didik menjawab maka pada slide berikutnya ditampilkan "susun alur keturunan 25 orang rasul", pada alur tersebut dilengkapi oleh nomor urutan mulai dari rasul pertama sampai terakhir.

Peserta didik diminta untuk mengamati alur tersebut dan mengingat urutannya. Setelah ditampilkan secara keseluruhan maka slide diulang dengan cara ditampilkan satu persatu berdasarkan urutan nomor. Setelah peserta didikmengamati dan mengingat urutannya maka slide kemudia ditutup. Peserta didik dibagi menjadi 3 kelompok yang masing masing terdiri dari 9 orang. Setelah kelompok siap maka mulai untuk quis. Pertanyaan telah disiapkan sebanyak 12 pertanyaan yang dibagi kedalam dua babak yaitu babak pertama pertanyaan wajib dijawab oleh setiap kelompok dengan menyebutkan nama rasul sesuai dengan nomor urutan, babak ini berisi 2 pertanyaan tiap kelompok. Pada babak kedua yaitu babak rebutan, pada babak ini ada 6 pertanyaan yang dibacakan dan setiap kelompok harus berebut untuk menjawabnya. Setelah semua pertanyaan selesai dibacakan, skor dari setiap kelompok kemudian dihitung dan menetukan pemenang. Demikianlah untuk pertemuan kedua pada materi beriman kepada Rasul Allah SWT.

Pertemuan ketiga, seperti pada pertemuan pertama dan kedua, sebelum memulai proses pembelajaran maka hal pertama yang dilakukan adalah menyiapkan alat pembelajaran. Seperti pada pertemuan pertama alat yang disiapkan adalah laptop, LCD, dan speaker. Setelah menyiapkan alat pembelajaran maka proses pembelajaran dibuka dengan mengucapkan salam dan berdoa sebelum belajar. Sebelum lanjut ke materi selanjutnya maka peserta didik di putarkan video nyanyian 25 nabi dan rasul untuk me-refresh ingatan pada pertemuan pertama. Pemutaran video cukup 2 kali kemudian peserta didik langsung ikut bernyanyi. Stelah itu ditampilkan slide berikutnya dengan materi “ Rasul-Rasul Ulul Azmi “, pada slide ini berisi penjelasan tentang maksud dari ululazmi, peserta didik diminta untuk membaca dan diberi penjelasan sedikit untuk memperjelas.

Slide kedua berisi materi "kelebihan yang dimiliki oleh rasul ululazmi". Slide ini dibacakan satu persatu agar peserta didik lebih paham dan merenungi betapa hebat dan kuasanya Allah swt. Setelah mendengarkan penjelasan maka 
slide berikutnya berisi "JOM Baca Komik". peserta didik diminta untuk mendengarkan dan memperhatikan komik yang ditampilkan. Setelah selesai peserta didik diminta untuk membuat kesimpulan dari komik tersebut. Setelah peserta didik menyampaikan kesimpulan kemudian ditampilkan slide berikutnya yang berisi renungan tentang sikap yang mestinya dilakukan dalam kehidupan sehari-hari. Setelah itu, ditampilkan pertanyaan yang berupa 5 kotak. Setiap kotak berisi pertanyaan. Peserta didik memilih salah satu kotak, kemudian pada slide berikutnya muncul pertanyaan yang ada dalam kotak, dan peserta didik wajib untuk menjawab pertanyaan tersebut. Apabila tidak bisa menjawab, maka dialihkan ke teman yang lain. Demikianlah pertemuan ketiga pada materi beriman kepada Rasul Allah swt.

Pertemuan keempat, seperti pada pertemuan pertama dan kedua, sebelum memulai proses pembelajaran maka hal pertama yang dilakukan adalah menyiapkan alat pembelajaran. Seperti pada pertemuan pertama, alat yang disiapkan adalah laptop, LCD, dan speaker. Setelah menyiapkan alat pembelajaran maka proses pembelajaran dibuka dengan mengucapkan salam dan berdoa sebelum belajar. Sebelum lanjut ke materi selanjutnya, maka peserta didik diputarkan video nyayian 25 nabi dan rasul untuk me-refresh ingatan pada pertemuan pertama. Pemutaran video cukup 1 kali kemudian peserta didik langsung ikut bernyanyi. Setelah itu ditampilkan slide berikutnya dengan materi "sifat-sifat rasul" kemudian pada slide berikutnya berisi empat sifat sifat wajib bagi rasul dan contohnya. Setelah membaca dan memahami selanjutnya ditampilkan slide tentang "Kisah doraemon", peserta didik diminta untuk merenungi kisah doraemon tersebut. Setelah itu diadakan pengayaan dengan menampilkan beberapa gambar tentang kebesaran Allah swt. Dan terakhir adalah latihan. Peserta didik diminta untuk menjawab langsung pertanyaan yang ada di slide. Demikianlah pertemuan ke empat dan terakhir untuk materi ajar iman kepada Rasul Allah swt.

Ruang lingkup pada penelitian ini adalah penerapan multimedia interaktif terhadap peningkatkan motivasi belajar aqidah akhlak di Madrasah Tsanawiyah Darul 'Ulum Ath-Thahiriyah Paladang. Berdasarkan variabel yang ada yaitu multimedia interaktif, dan motivasi belajar aqidah akhlak terdapat beberapa indikator dari masing-masing variabel. Indikator motivasi belajar dijadikan acuan untuk membuat instrumen tes motivasi. Adapun indikator dari multimedia interaktif dijadikan acuan untuk multimedia yang dipakai dalam proses perlakuan. Uraian indikator dari variabel multimedia interaktif dan motivasi belajar diuraikan pada tabel berikut: 


\begin{tabular}{|c|c|c|}
\hline No. & Variabel & Indikator \\
\hline 1. & Multimedia Interaktif & $\begin{array}{l}\text { Berisi konten materi akidah akhlak yang } \\
\text { representatif dalam bentuk visual, audio dan } \\
\text { audiovisual. } \\
\text { Memiliki kekuatan warna, bahasa dan } \\
\text { resolusi objek. } \\
\text { Tipe-tipe pembelajaran yang bervariasi. } \\
\text { Respons pembelajaran dan penguatan } \\
\text { bervariasi. } \\
\text { Mengembangkan prinsip belajar bermakna } \\
\text { dan menyenangkan. } \\
\text { Digunakan secara klasikal atau individual. } \\
\text { Digunakan secara offline. }\end{array}$ \\
\hline 2 & Motivasi belajar & $\begin{array}{l}\text {-Motivasi intrinsik } \\
\text { Antusias tinggi. } \\
\text { Mengendalikan perhatian dan energinya } \\
\text { pada proses pembelajaran } \\
\text { Tekun menghadapi tugas. } \\
\text { Senang dan rajin belajar, penuh semangat, } \\
\text { cepat bosan dengan tugas-tugas rutin, dapat } \\
\text { mempertahankan pendapatnya. } \\
\text {-Motivasi ekstrinsik } \\
\text { Tertarik pada media pembelajaran akidah } \\
\text { akhlak berbasis multimedia artinya tidak } \\
\text { acuh tak acuh. } \\
\text { Tertarik pada mata pelajaran yang diajarkan. } \\
\text { Variasi aktivitas belajar lebih banyak. }\end{array}$ \\
\hline
\end{tabular}

Tabel 1. Ruang Lingkup Penelitian

\section{PEMBAHASAN}

\section{Penerapan Multimedia Interaktif dapat Meningkatkan Motivasi Belajar Peserta Didik: Motivasi Intrinsik}

Motivasi intrinsik merupakan motivasi yang mempengaruhi peserta didik yang berasal dari dalam diri peserta didik tersebut. Adapun motivasi intrinsik yang dibahas pada penelitian ini adalah antusias tinggi, mengendalikan perhatian dan energinya pada proses pembelajaran, tekun menghadapi tugas, senang dan rajin belajar, penuh semangat, cepat bosan dengan tugas-tugas rutin, dan mempertahankan pendapatnya pada proses pembelajaran.

\section{Antusias Tinggi}

Antusias tinggi merupakan salah satu motivasi intrinsik yang ditandai oleh gairah, semangat dan minat yang tinggi terhadap sesuatu. Antusias ini 
merupakan dorongan yang sangat kuat dari dalam diri peserta didik. Setelah penggunaan multimedia interaktif pembelajaran akidah akhlak, diperoleh hasil post tes yang sangat tinggi, hal tersebut terlihat dari kegiatan peserta didik dalam proses pembelajaran yang berkeyakinan kuat untuk mendapat nilai yang tinggi pada proses pembelajaran akidah akhlak dengan menggunakan media pembelajaran akidah akhlak berbasis multimedia pembelajaran.

\section{Mengendalikan perhatian dan energinya pada proses pembelajaran}

Mengendalikan perhatian dan energinya pada proses pembelajaran merupakan motivasi dari dalam diri peserta didik yang mendorongnya untuk mempertahankan perhatian dan tetap fokus dalam proses pembelajaran dalam kelas. Serta energinya digunakan dengan sebaik-baiknya dan tidak memperlihatkan kelelahan dalam belajar. Setelah diberi perlakuan penggunaan multimedia interaktif, diperoleh hasil post tes yang sangat tinggi. Hal tersebut dapat dilihat pada kegiatan peserta didik dalam proses pembelajaran yang mempertahankan perhatian dan energinya dalam proses pembelajaran, tidak lagi jalan-jalan di kelas saat guru menjelaskan materi ajar dan tidak membuat keributan di kelas.

\section{Tekun menghadapi tugas dalam proses pembelajaran}

Tekun menghadapi tugas dalam proses pembelajaran merupakan dorongan dari dalam diri peserta didik untuk mngerjakan tugas atau latihan yang diberikan oleh guru. Tugas dikerjakan dengan penuh kesungguhan dan tidak memperlihatkan rasa lelah dan bosan dalam mengerjakan tugas atau layihan yang diberikan. Setelah diberi perlakuan multimedia interaktif, diperoleh hasil post tes yang tinggi sekali. Hal tersebut terlihat pada kegiatan peserta didik dalam proses pembelajaran yang sudah tidak terlalu sulit lagi dalam mengerjakan tugas-tugas latihan dalam proses pembelajaran akidah akhlak dengan materi beriman kepada rasul Allah swt.

\section{Senang dan rajin belajar, penuh semangat, cepat bosan dengan tugas- tugas rutin, dapat mempertahankan pendapat.}

Senang dan rajin belajar, penuh semangat, cepat bosan dengan tugastugas rutin serta dapat mempertahankan pendapatnya merupakan ciri peserta didik yang memiliki motivasi belajar yang tinggi. Perasaan yang dirasakan saat proses pembelajaran begitu kuat dan kondisi saat belajar selalu memperlihatkan situasi yang menyenangkan dan menjadikan proses pembelajaran menjadi lebih bermakna. Setelah diberi perlakuan penggunaan multimedia interaktif, diperoleh hasil post tes yang sangat tinggi. Hal tersebut dapat dilihat pada kegiatan proses pembelajaran akidah akhlak yang sudah tidak bosan lagi dengan jumlah 
pengulangan materi pembelajaran beriman kepada rasul Allah swt. tidak lagi melamun ketika guru menampilkan materi ajar dan tidak tidur lagi di dalam kelas.

\section{Motivasi Ekstrinsik}

Adapun motivasi ektrinsik yang dibahas pada penelitian ini adalah tertarik pada media pembelajaran yang digunakan, tertarik pada materi ajar yang diajarkan dan pembelajaran yang lebih bervariasi. Secara lebih rinci dijelaskan sebagai berikut:

\section{Tertarik pada media pembelajaran akidah akhlak berbasis multimedia artinya tidak acuh tak acuh.}

Perpaduan antara teks, gambar, video, dan audio yang digunakan guru dalam proses pembelajaran dapat memicu semangat dan antusias peserta didik dalam mengikuti proses pembelajaran akidah akhlak. Dalam hal ini peneliti sendiri berusaha untuk membuat peserta didik termotivasi dengan media yang digunakan dalam proses pembelajaran akidah akhlak. Peneliti melakukan perlakuan berupa penggunaan media pembelajaran akidah akhlak berbasis multimedia interaktif pada mata pelajaran beriman kepada rasul Allah swt. menggunakan aplikasi power point dan menampilkan video menghafal namanama nabi dan rasul ululazmi, teks dengan tulisan yang berwarna dan berbagai jenis, bunyi pergantian slide, kisah-kisah yang menarik gambar-gambar yang mendukung materi ajar. Hal tersebut meningkatkan motivasi belajar peserta didik yang terlihat pada hasil post tes yang sangat tinggi. Hasil tersebut dapat ditunjukkan bahwa peserta didik dapat mengambil manfaat dari cerita yang ditampilkan, bersemangat menbaca materi beriman kepada rasul Allah swt. karena gaya tulisan yang bervariasi, sebagian besar materi ajar sudah dikuasai dan tidak lagi mencari referensi media lain dalam proses pembelajaran akidah akhlak.

\section{Tertarik pada mata pelajaran yang diajarkan.}

Mata pelajaran akidah akhlak adalah mata pelajaran tentang tauhid dan akhlak manusia dalam kehidupan sehari-hari, untuk memotivasi peserta didik agar semangat belajar materi akidah akhlak yaitu dengan menyajikan materi ajar yang menarik dan mudah dipahami oleh peserta didik. Dalam hal ini peneliti menyajikan materi ajar akidah akhlak dengan menarik dan mudah dipahami oleh peserta didik, hal ini terlihat pada hasil post tes sangat tinggi. Hal tersebut menunjukkan bahwa setelah dilakukan perlakuan maka peserta didik memiliki keinginan tinggi dalam mengikuti pelajaran akidah akhlak. 


\section{Variasi aktivitas belajar lebih banyak}

Variasi aktivitas belajar lebih banyak berarti peserta didik memperoleh informasi belajar bukan hanya dari informasi guru pembimbing saja, melainkan peserta didik lebih kreatif dalam mencari informasi belajar. Namun setelah diberi perlakuan, hasil post tes menunjukkan adanya peningkatan dari sebelum diberi perlakuan dan termasuk dalam kategori sangat tinggi. Bila dalam kelas ditunjukkan aktivitas belajar ebih banyak dan bukan hanya mendengarkan penjelasan dari guru melainkan peserta didik lebih mencatat hal penting dan menyiapkan pertanyaan untuk diajukan kepada guru, saling bertukar fikiran dengan teman kelompok dan antusias menjawab pertanyaan yang diberikan oleh guru.

\section{SIMPULAN}

Berdasarkan hasil penelitian di kelas VIII MTs Pondok Pesantren AthThahiriyah Paladang, maka dapat disimpulkan bahwa motivasi peserta didik mengikuti proses pembelajaran akidah akhlak sesudah diberi perlakuan berupa penerapan multimedia interaktif meningkat. Hal tersebut dapat diketahui dari hasil uji t-tes yang menunjukkant hitung $(6,621)>t$ tabel $(2,05553)$ dan hasil analisis tiap-tiap indikator yakni $89,99 \%$. Hal tersebut menunjukkan adanya hubungan yang signifikana ntara penerapan multimedia interaktif dengan peningkatan motivasi belajar peserta didik. Oleh karena itu, penerapan multimedia interaktif efektif untuk meningkatkan motivasi belajar peserta didik mengikuti proses pembelajaran akidah akhlak. Dengan demikian, hipotesis yang diajukan diterima.

\section{REFERENCE}

(1) Abdul Wahab, Solichin. Analisis Kebijaksanaan Negara. Jakarta: Rineka Cipta. 1990.

(2) Admaja, Purwa Prawira. Psikologi Pendidikan dalam Persfektif Baru. Jogjakarta: Ar-Ruzz Media. 2011.

(3) Arsyad. Media Pembelajaran. Jakarta: PT RajaGrafindo Persada. 2010.

(4) Badudu. Inilah Bahasa Indonesia Yang Benar. Jakarta: PT Gramedia Pustaka Utama. 1996

(5) Cahyono, Bambang. Pengembangan Aplikasi Multimedia Pembelajaran Untuk Meningkatkan Hasil Belajar Matematika Di SMP Muhammadiyah 3 Depok Kelas VIII C Tahun Pelajaran 2012/2013. Tesis. Diakses dihttp://ejournal.uajy.ac.id/1255/1/0MTF01614.pdf, Pada Tanggal 10 Oktober 2016.

(6) Dermawan, Deni. Inovasi Pendidikan (Pendekatan Praktik Teknologi Multimedia Dan Pembelajaran Online). Bandung: PT Remaja Rosdakarya. 2014. 
(7) Furqan, Arief. Pengantar Penelitian Dalam Pendidikan. Yogyaakarta: Pustaka Pelajar. 2011.

(8) Gay, Geoffrey, Mills, Peter Airasian. Educational Research Competencies For Analysis And Applications. Pearson Education: America. 2012.

(9) Hasrul. Desain Media Pembelajaran Animasi Berbasis Adove Flash Cs3 Pada Mata Kuliah Instalasi Listrik 2. Jurnal MEDTEK. Malang: Vol. 3. No. 2/Oktober2011.

(10) Kasiram, Moh. Metodologi Penelitian. Malang: UIN-Maliki Press, 2010.

(11) Margono. Metodologi Penelitian Pendidikan. Jakarta: PT Rineka Cipta. 2004

(12) Mayer, Richard E. Multimedia Learning Second Edition. Cambridge University Press: New York. 2009.

(13) Muhamad, Ali. Pengembangan Media Pembelajaran Interaktif Pada Mata Kuliah Medan Elektromagnetik. Jurnal Edukasi. Yogyakarta: Vol. 5, No. 1/Maret 2009.

(14) Mohammad, Nur Supriadi. Pengaruh Multimedia Dan Motivasi Belajar Terhadap Keterampilan Mata Kuliah Kebutuhan Dasar Manusia. Tesis. Diakses di http://eprints.uns.ac.id/13823/1/318862509201311372.pdf. Pada Tanggal 10 Oktober 2016.

(15) Munir. Prospek Komputer Sebagai Media Pembelajaran Interaktif Dalam Sistem Pendidikan Jarak Jauh di Indonesia. diakses dari http://file.upi.edu/Direktori/, pada tanggal 29 Juli 2010.

(16) Padmanthara. Pembelajaran Berbantuan Komputer Dan Manfaat Sebagai Media Pembelajaran. dalam Jurnal TEKNODIK. Vol. 22. Pp, 2007. h. 130144.

(17) Rahman, Abdul Saleh, Muhbib Abdul Wahab. Psikologi Suatu Pengantar Dalam Perfektif Islam. Jakarta:Kencana. 2004.

(18) Riduwan dkk. Pengantar statistika untuk penelitian pendidikan, sosial, ekonomi, komunikasi, dan bisnis. Bandung: alfabeta. 2015

(19) Rizqi, Fimel. Hadits Tentang Media Pembelajaran. diakses dari http://fimelrizqi.blogspot.co.id/2012/04/hadits-tentang-mediapembelajaran.html, pada tanggal 28 september 2016.

(20) Sanjaya, Wina. Perencanaan dan Desain Sistem Pembelajaran. Jakarta: Kencana Prenada Media Group. 2010.

(21) Santrock, John W.Psikologi Pendidikan. Jakarta: PT Fajar Interpratama Offset. 2010.

(22) Sukardi. Metodologi Penelitian Pendidikan Kompetensi Dan Praktiknya. Jakarta: PT Bumi Aksara. 2010.

(23) Tim Penyusun Pedoman Penulisan Karya Ilmiah. Pedoman Penulisan Karya Ilmiah. Parepare: STAIN Parepare. 2014.

(24) Trianto. Pengantar Penelitian Pendidikan Bagi Pengembangan Profesi Pendidik dan Tenaga Kependidikan. Jakarta: Kencana Prenada Media Group: 2010. 
(25) Uno, Hamzah B. dan Masri Kuadrat. Mengelola Kecerdasan Dalam Pembelajaran: Sebuah Konsep pembelajaran Berbasis Kecerdasan. Jakarta: Bumi Aksara. 2009.

(26) Yuliani. Pengembangan Multimedia Pembelajaran IPS Untuk Siswa SMP Kelas VII, Tesis. diakses Di http : //eprints.uns.ac.id/10043/1/186101511201110061.pdf. Pada Tanggal 10 Oktober 2016.

(27) Parker, Lyn, Irma Riyani, and Brooke Nolan. "The Stigmatisation of Widows and Divorcees (janda) in Indonesia, and the Possibilities for Agency." Indonesia and The Malay World 44, no. 128 (2016).

(28) Internet

(29) Yahya, Harun. “Keajaiban Hujan,” 2011. Diakses tanggal 13 Oktober 2016. http://id.harunyahya.com/id/Artikel /38832/KEAJAIBAN-HUJAN.

(30) Wawancara

(31) Fery, Fahruddin (Mahasiswa), wawancara oleh Miftah. Sekolah Tinggi Agama Islam Kudus. Tanggal 1 Mei 2016. 